\title{
When and where did hybridization occur? The case of the Monte Capanne Pluton, Italy
}

\author{
D.S. Westerman ${ }^{1}$, A. Dini ${ }^{2}$, F. Innocenti ${ }^{3}$ and S. Rocchi ${ }^{3}$ \\ 1. Department of Geology, 158 Harmon Drive, Norwich University, Northfield, Vermont 05663 \\ 2. Istituto di Geoscienze e Georisorse - CNR, Via Moruzzi 1, Pisa, I-56124, Italy \\ 3. Dipartimento di Scienze della Terra, Via Santa Maria 53, Università di Pisa, Pisa I-56126, Italy
}

Date received:August 8, 2003 g Date accepted: March 4, 2004

\begin{abstract}
The Monte Capanne pluton was emplaced during the Late Miocene in a post-collision extensional regime that generated the Tuscan Magmatic Province as the Adriatic (lower) plate underwent progressive crustal delamination. This dominantly monzogranitic pluton, generated by hybridization between mantle and crustal magmas, consists of mappable facies; end members range from less hybridized with high concentrations of very coarse K-feldspar megacrysts and abundant mafic microgranular enclaves, to more hybridized with low megacryst and enclave abundances. K-feldspar megacrysts from Monte Capanne and other related units of the province, along with their inclusions and associated late mineral phases, preserve evidence of chemical and ${ }^{87} \mathrm{Sr} /{ }^{86} \mathrm{Sr}$ disequilibrium (first rising and then falling) during evolution of the system. The concomitant occurrence of contrasting reaction microtextures in accessory phases in this anatectic-hybrid pluton, particularly involving monazite-(Ce), also suggests transient chemical conditions. The ubiquitous mafic microgranular enclaves, typically with high concentrations of xenocrysts from Monte Capanne magma, provide evidence of a highly dynamic system involving vigorous interaction between mafic and felsic magmas. The data suggest that rapid dehydration melting, driven by intrusions of fractionating mantle-derived magma near the base of the crust, was followed by magma mixing and K-feldspar megacryst growth. Segregation and ascent produced the hybridized products now observed at the emplacement level.
\end{abstract}

\section{RÉSUMÉ}

L'intrusion du pluton du mont Capanne est survenue au cours du Miocène tardif dans un régime d'extension de post-collision ayant produit la province magmatique de Toscane au fur et à mesure que la plaque (inférieure) de l'Adriatique a subi une delamination crustale progressive. Ces plutons principalement monzogranitiques, produits par hybridation entre les magmas mantéliques et crustaux, sont constitués de faciès cartographiables; les membres d'extrémité varient des membres peu hybridés renfermant de fortes concentrations de mégacristaux de feldspath potassique très grossiers et d'enclaves microgranulaires mafiques abondantes à des membres plus hybridés comportant de faibles abondances d'enclaves et de mégacristaux. Les mégacristaux de feldspath potassique du mont Capanne et des autres unités apparentés de la province, de même que leurs inclusions et leurs phases minérales tardives associées, préservent les indices d'un déséquilibre chimique et de ${ }^{87} \mathrm{Sr} /{ }^{86} \mathrm{Sr}$ (d'abord hausse, puis baisse) pendant l'évolution du système. La présence concomitante de microtextures à réactions opposées au cours de phases accessoires dans ce pluton anatectique-hybride, mettant en scène en particulier de la monazite-(Ce), permet par ailleurs de supposer des conditions chimiques transitoires. Les enclaves microgranulaires mafiques ubiquistes, présentant généralement des concentrations élevées de xénocristaux du magma du mont Capanne, témoignent d'un système extrêmement dynamique présentant une interaction prononcée entre les magmas mafiques et felsiques. Les données laissent supposer qu'une fusion à déshydratation rapide, animée par les intrusions de magma mantélique s'étant fractionné près de la base de la croûte, a été suivie d'un mixage de magma et de la croissance de mégacristaux de feldspath potassique. La ségrégation et l'ascension magmatiques ont fourni les produits hybridés maintenant observés au niveau de l'intrusion.

[Traduit par la rédaction]

\section{INTRODUCTION}

Interaction of partially molten materials (hybridization) commonly occurs in the crust when mantle-derived magma provides the heat for crustal melting. This interaction begins as early as the onset of anatectic melting in the source region, with direct interaction between the magmas or incorporation of enclaves into the crustal melt, with diffusion across contacts, and phenocryst transfer between mafic and felsic magmas. In addition to interacting, such melts can evolve independently as well. Dehydration melting of crustal sources is commonly accompanied by growth of crystals that are products of dehy- 
dration reactions; those products remain as part of the evolving magmatic system. Crystallization can also occur either continuously once a phase is nucleated, or intermittently, depending on changes in P-T-composition conditions either in the melt zone, during ascent, at any resting levels temporarily occupied, or in the final emplacement level. And finally, the intrusion of mantle-derived magmas, crustal melting, magma extraction, and emplacement can occur in simple steps or in a complex pattern spread through both space and time. Clearly, magmatic systems producing granitoids need to be examined holistically, from source to final exposure (Petford et al.2000), or from «cradle to grave».

Several crustal- and mantle-derived melts were involved in the generation of the intrusive and extrusive units making up the Tuscan Magmatic Province (TMP) of central Italy (Dini et al. 2002; Innocenti et al. 1992). The Monte Capanne pluton is made up of a range of hybrid products derived by modification of one of these anatectic melts, along with another group of products derived by modification of mantle-derived magmas. Hybrids dominated by the crustal melts are expressed by the various facies of the Monte Capanne pluton, whereas the mafic magma hybrids are represented by the ubiquitous presence of a wide variety of mafic microgranular enclaves. In this paper, we explore how a detailed petrographic, geochemical, and isotopic study of such a complex system can document processes in the source area that created a broad variety of products long before these materials ever reached their emplacement levels.

\section{GEOLOGIC AND TECTONIC SETTING}

\section{Regional geology}

The Monte Capanne pluton is located on Elba Island at the northern end of the Tyrrhenian Sea (Fig. 1), a region affected by extensional processes behind the eastward-progressing front of the Apennine mobile belt. The backbone structure of the Apennines was constructed when the Sardinia-Corsica block collided with the Adria plate (Malinverno and Ryan 1986). This orogenic system evolved diachronously (Fig. 2) as the extensional regime migrated from west to east, trailing the retreat of the compressive regime (Brunet et al. 2000) and giving way to the opening of the ensialic back-arc Tyrrhenian basin.

Igneous activity associated with extensional processes also migrated from west (14 Ma) to east ( $0.2 \mathrm{Ma}$ ) as the west-dipping Adriatic plate delaminated and rolled back to the east (Serri et al. 1993). Intrusive and extrusive rocks that represent hybrids of crust- and mantle-derived magmas built the TMP, spreading over about $30000 \mathrm{~km}^{2}$ in southern Tuscany and the northern Tyrrhenian Sea (Dini et al. 2002; Innocenti et al. 1997; Poli 1992; Westerman et al. 1993). Individual intrusive units vary in their compositional ranges, as well as in the range of compositions of their included mafic microgranular enclaves. Variability of the products making up this province has been well documented, particulaly with the use of ${ }^{143} \mathrm{Nd} /{ }^{144} \mathrm{Nd}$ vs. ${ }^{87} \mathrm{Sr} /{ }^{86} \mathrm{Sr}$ studies (Dini et al. 2002).

\section{The geology of Elba Island}

\section{Pre-intrusive setting}

The structure of Elba Island consisted of five tectonic complexes (Fig. 1) that were stacked onto each other by about 20 $\mathrm{Ma}$ (Deino et al. 1992). The lower three(I-III) have continental features, consisting of metamorphic basement and shallowwater clastic and carbonate rocks, whereas the upper two (IVV) are oceanic in character (Keller and Pialli 1990; Pertusati et al. 1993; Trevisan 1950). In more detail, Complex IV consists of Jurassic oceanic lithosphere of the western Tethys Ocean and its late Jurassic-middle Cretaceous sedimentary cover, all deformed and metamorphosed during the Apenninic compression to form east-verging folds. Complex $\mathrm{V}$ consists of Paleocene to middle Eocene flysch, overthrust by an upper Cretaceous flysch sequence (Keller and Pialli 1990).

\section{The intrusive sequence}

Extensional processes and igneous activity affected Elba Island during the late Miocene (Bouillin et al. 1993; Jolivet et al. 1994; Serri et al. 1993). Field, petrographic, and geochemical data, along with intrusive relationships, have been used to define several Miocene intrusive units in western and central Elba and to correlate them between exposures (Dini et al. 2002). Ranges of composition are reported in the total alkali vs. silica (TAS) diagram (Fig. 3; Le Bas et al. 1986) to illustrate overall chemical compositions of the intrusive units. The relative chronology of the intrusive sequence has been firmly established on the basis of crosscutting relations supported by isotope chronology (Dini et al. 2002). The magmatic sequence led to the formation of a nested Christmas-tree laccolith complex with a total thickness of about $2400 \mathrm{~m}$ of porphyritic rocks emplaced at depths of $2-3.5 \mathrm{~km}$ (Rocchi et al. 2002; Westerman et al. 2004). This complex was then intruded by the Monte Capanne pluton, portions of which were intruded by the Orano dyke swarm before complete consolidation.

The first episode of magmatism, with products derived completely from a felsic source (Dini et al. 2002), occurred around 8 Ma. This episode started with emplacement of the Capo Bianco porphyritic aplite, with alkali feldspar granite composition, followed by the Nasuto micro-syenogranite. Both of these units were then intruded by the younger Portoferraio porphyry with compositions ranging from monzogranite to syenogranite, and prominent phenocrysts of sanidine. This much more voluminous intrusion formed the Christmas-tree laccolith made up of four major layers which are interconnected and accompanied by minor dykes and sills. All together, this episode of magma-

Fig. 1 Geologic map and cross section of Elba Island. Abbreviations: SMF is the main feeder dyke for the San Martino laccolith; EBF is the Eastern Border fault; $\mathrm{CEF}$ is the Central Elba fault; ZF is the Zuccale fault. 


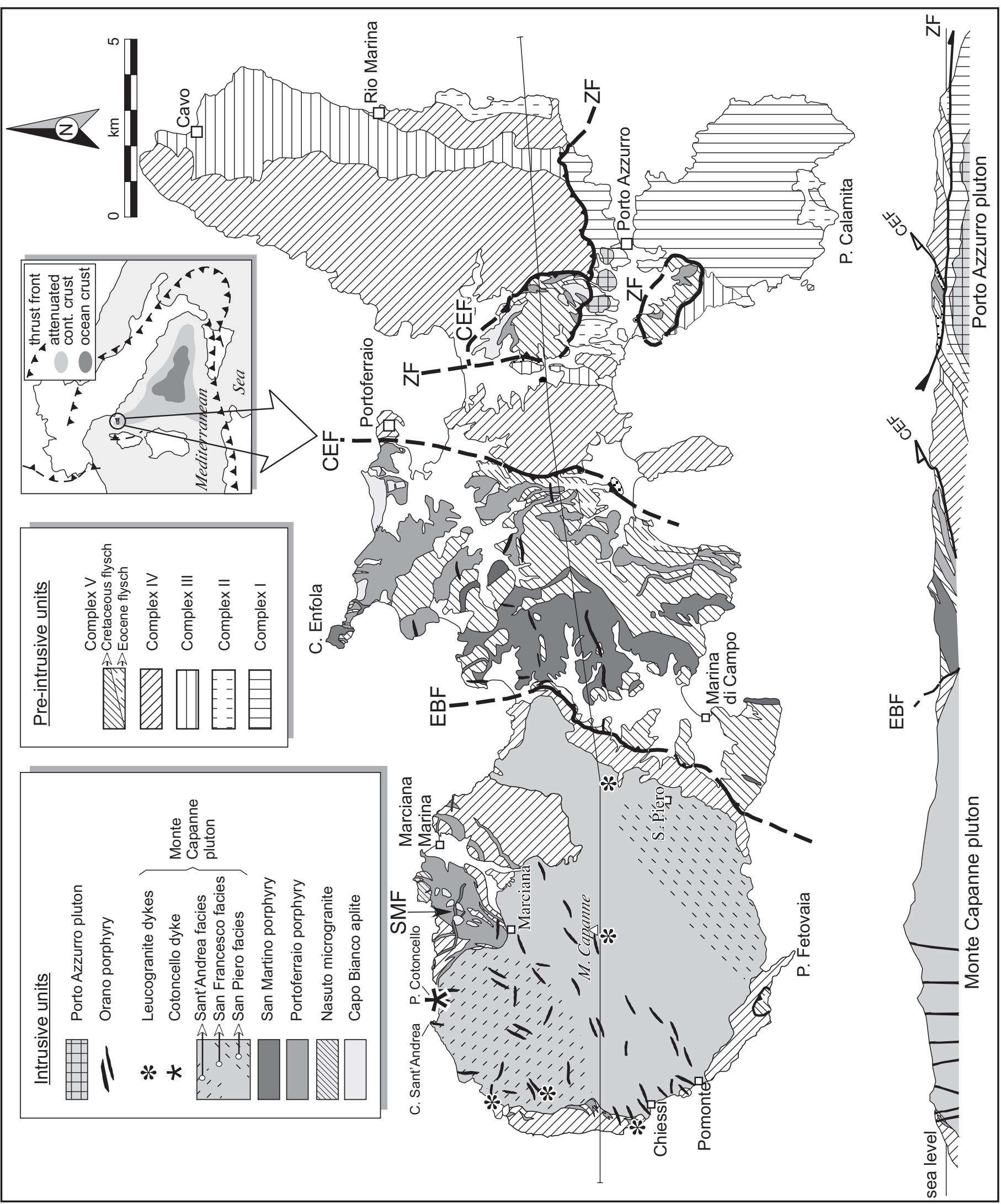




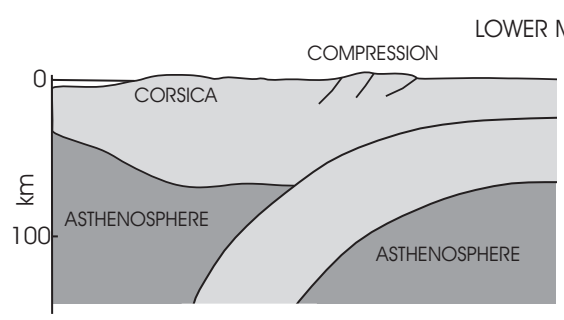

LANGHIAN - EARLY TORTONIAN
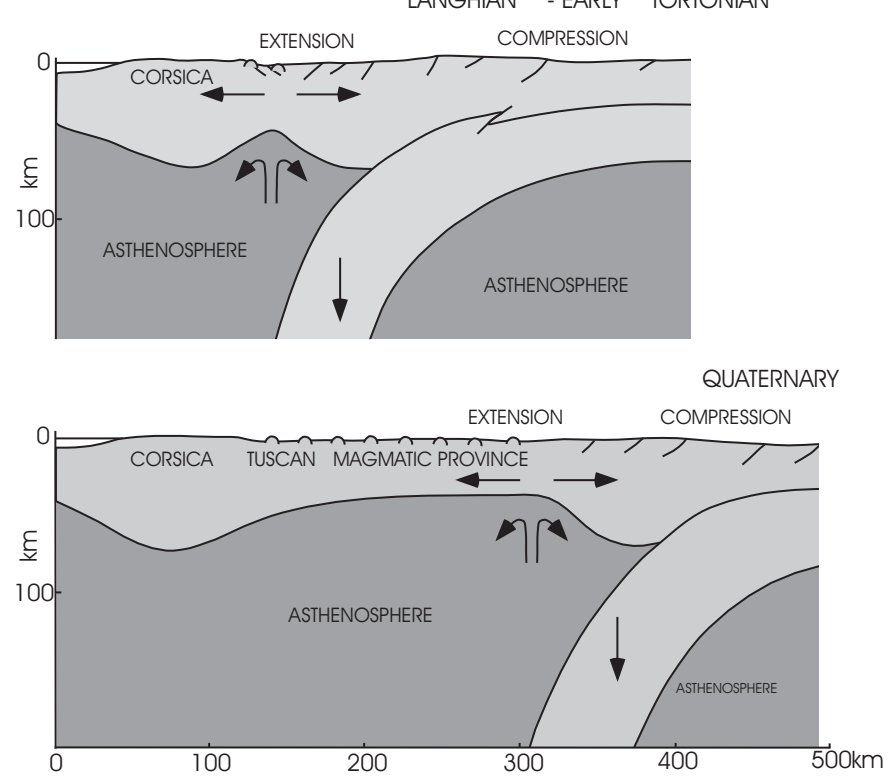

Fig. 2 Schematic geodynamic model showing the eastward migration of compression, trailing extension, and the resulting Tuscan magmatism (after Serri et al. 1993).

tism added about $1400 \mathrm{~m}$ of intrusive layers in the upper crust above western Elba (Fig. 4; Rocchi et al. 2002).

Emplacement of the San Martino porphyry marked a second episode of magmatism at approximately 7.4 Ma, this time involving a crustal magma along with a mantle-derived magma (Dini et al. 2002). This monzogranite porphyry occurs as thick layers and dykes characterized by prominent megacrysts of sanidine (up to $15 \mathrm{~cm}$ ) set in a very fine-grained groundmass. In western Elba where the deeper part of the tectonostratigraphic section is exposed, the San Martino porphyry occurs only as dykes with lengths up to $2.5 \mathrm{~km}$ and thicknesses of 25 to 50 $\mathrm{m}$. Higher in the section, exposed in central Elba, the main intrusion formed a Christmas-tree laccolith with four parallel, gently westward-dipping layers (cumulative thickness of about $1000 \mathrm{~m}$ ) connected by dykes. At this stage, the nested Christmas-tree laccolith complex was fully developed with about $2400 \mathrm{~m}$ of new intrusive material added to a $2700 \mathrm{~m}$ section of host rock, forming a structural dome with a diameter of about $10 \mathrm{~km}$ and relief over $2 \mathrm{~km}$ (Fig. 4; Rocchi et al. 2002; Westerman et al. 2004).

A third episode of magmatism began with emplacement of the Monte Capanne pluton in western Elba at about 6.9 Ma (Dini et al. 2002). The pluton is roughly circular in outcrop with a diameter of about $10 \mathrm{~km}$ and relief of $1 \mathrm{~km}$.

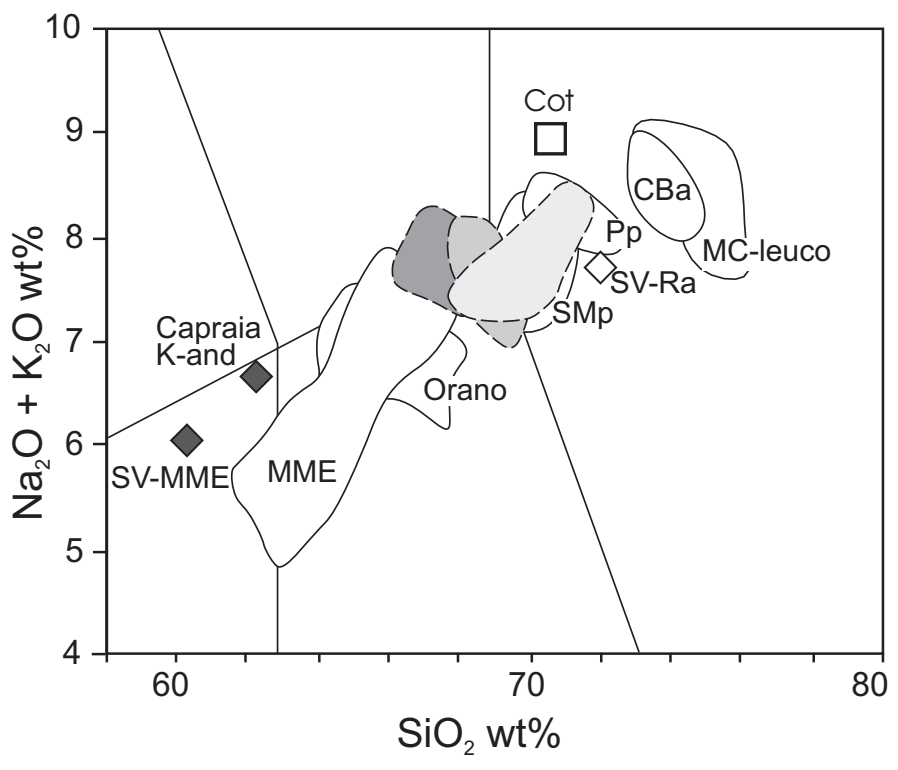

Fig. 3 Total alkali vs. silica (TAS) classification diagram (Le Bas et al. 1986). Shaded fields show San Piero facies (darkest), San Francesco facies (intermediate) and Sant'Andrea facies (palest); all three facies plot near the junction of the quartz monzonite, granodiorite, and granite fields of Middlemost (1994).

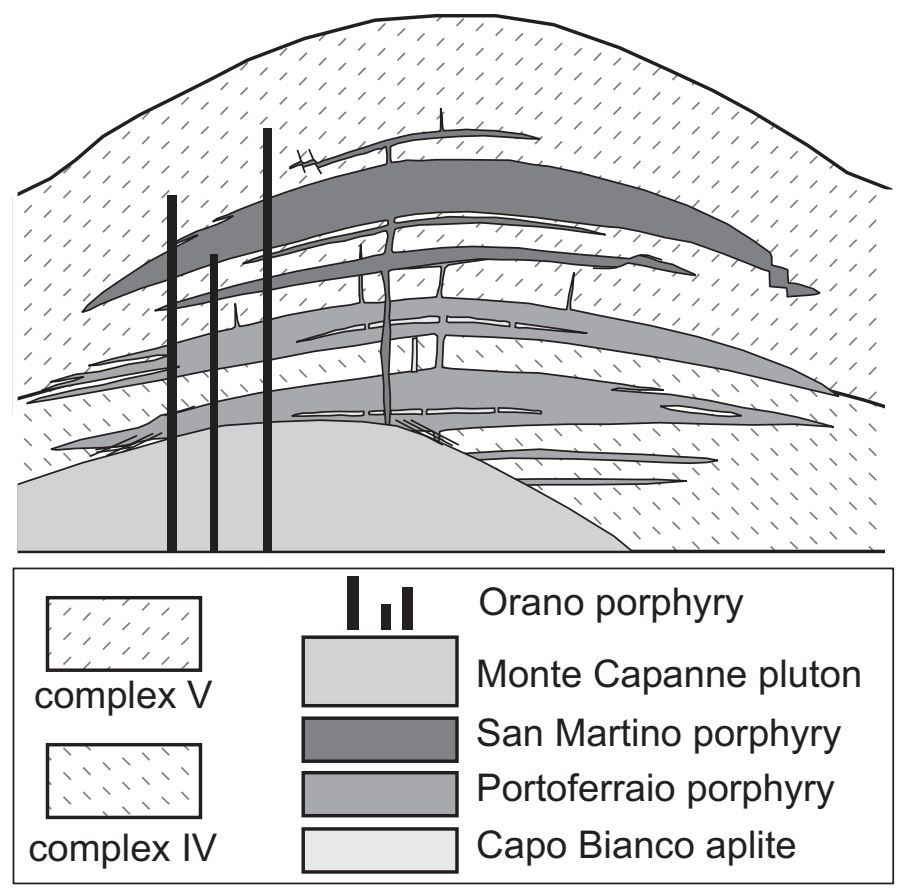

Fig. 4 Schematic reconstruction of the Elba Christmas-tree laccolith complex and younger intrusions illustrating the fully developed structural dome before its tectonic dismemberment. 
Overall, it contains prominent $\mathrm{K}$-feldspar megacrysts and is monzogranitic in composition with three internal facies recognized. Contacts with surrounding country rock, including the laccolith units of the dome, are mostly intrusive in nature and dip away from the pluton. Host rocks, belonging to the ophiolitic-sedimentary tectonic Complex IV, were overprinted by thermal metamorphism and deformed by emplacement of the pluton itself(Daniel and Jolivet 1995). Lithologic varieties of protoliths in the aureole preserve the reactions that, taken together, suggest peak contact metamorphic conditions with temperatures in excess of $600^{\circ} \mathrm{C}$ at a pressure of $0.1-0.2 \mathrm{GPa}$ (Dini et al. 2002). This pressure estimate matches well with an emplacement depth of $4.5 \mathrm{~km}$ based on reconstruction of the overlying section (Westerman et al. 2004). The pluton is cut by several leucosyenogranite dykes and lenses (10's of $\mathrm{m}$ thick), occurring mainly close to the pluton's contact (Fig. 1), both within the pluton and in its thermal aureole. Aplite - pegmatite veins and dykes occur commonly, generally less than $2 \mathrm{~m}$ thick and extending only several meters along strike.

Culmination of the third magmatic episode was marked by emplacement of the Orano porphyry unit, an E-W-trending swarm of nearly 100 darkly coloured quartz monzodioritic to granodioritic dykes that intruded all of the other intrusive units of the sequence about 6.8-6.9 Ma (Dini et al. 2002). Contacts with host rock are sharp and planar, commonly exhibiting abrupt changes in orientation. Thicknesses range from less than a meter up to a maximum of $50 \mathrm{~m}$. Thicker dykes tend to be composite, with central portions containing higher concentrations of microgranular enclaves and xenocrysts of Monte Capanne mineralogy as well. With emplacement of the Monte Capanne pluton and the Orano dyke swarm, the structural dome at this magmatic center was approaching instability with slopes on the order of $25^{\circ}$ (Fig. 4; Westerman et al. 2004).

\section{Post-intrusive evolution}

Western and central Elba are separated by the Eastern Border fault that parallels the east side of the Monte Capanne pluton and truncates its contact aureole (Fig. 1). The Eastern Border fault dips moderately to steeply to the east, separating a western footwall breccia of hornfelsed Complex IV rocks plus fragments of the Monte Capanne pluton from an eastern hanging wall breccia of Complex V flysch and megacrystic San Martino porphyry (Rocchi et al. 2002). Central Elba is separated from eastern Elba by the low-angle Central Elba fault (Fig. 1), marked by a tectonic mélange of rocks from Complexes IV and V, most notably rocks whose equivalents crop out in western Elba (Marinelli 1955; Vom Rath 1870). The fault dips gently westward, such that the highest part of the stratigraphic section occurs at the western edge of central Elba against the east-dipping Eastern Border fault.

Décollement on the Central Elba fault was apparently initiated on the Complex IV - V tectonic contact (Fig. 4) with the top half of the laccolith complex displaced at least $8 \mathrm{~km}$ eastward, a distance estimated from clasts of hornfels from the Monte Capanne aureole occurring in the footwall breccia at that distance. Concurrent or subsequent uplift of western Elba occurred on the Eastern Border fault with 2-3 km of vertical throw, producing a serendipitous sequence of exposures that allows observation of nearly the complete section of the igneous complex, including $1 \mathrm{~km}$ of relief of the Monte Capanne pluton (Westerman et al. 2004).

\section{MONTE CAPANNE PLUTON}

The Monte Capanne pluton is the largest of the exposed TMP plutons and the most extensively studied petrologically (Bussy 1990; Dini et al. 2002; Marinelli 1955; Marinelli 1959; Poli 1992; Poli et al. 1989). With an exposed diameter of $10 \mathrm{~km}$ bordered along two thirds of its perimeter by contact metamorphosed rocks (Fig. 1), and an estimated thickness of $2 \mathrm{~km}$ on the basis of preliminary magnetic modeling (O. Faggioni, personal communication, 2003), its total volume is on the order of $150 \mathrm{~km}^{3}$.

\section{Petrography}

The main pluton shows minor variability of its petrographic features. Most samples are monzogranite but approach granodiorite in composition. Internal facies with diffuse transitions have been identified in the field. The more evolved end-member is the "Sant'Andrea facies" and the less evolved end-member is the "San Piero facies". They are separated by a wide zone of "San Francesco facies" with transitional characteristics (Fig. 1; Dini et al. 2002). The Sant'Andrea facies is exposed most abundantly along the northwestern margin of the pluton, but also occurs as scattered patches elsewhere, which led early workers to refer to it as the border facies (Marinelli 1959). The mineral assemblage of all the facies is dominated by the typical association of plagioclase, quartz, K-feldspar and biotite.

$\mathrm{K}$-feldspar megacrysts in the Monte Capanne pluton are ubiquitous, although their size, concentration, degree of alignment, and visibility vary widely. They are typically euhedral, 5-9 cm long (Fig. 5a), locally reaching $20 \mathrm{~cm}$, and they sometimes have ragged poikilitic margins containing uniformly distributed inclusions of matrix minerals. K-feldspar megacrysts commonly exhibit well-developed hourglass zoning (Fig. 5b; Vernon 1986) defined by minute, oriented euhedral biotite inclusions $(\mathrm{Mg} /(\mathrm{Mg}+\mathrm{Fe})$ atomic ratio $(\mathrm{Mg} \#)=0.55 ; \mathrm{Rb} / \mathrm{Sr}=$ 162-244). Also present as inclusions of similar size are quartz, apatite, zircon and monazite, as well as crystallographically aligned plagioclase $\left(\mathrm{An}_{39}-\mathrm{An}_{21}\right)$ that exhibit concentric oscillatory zoning (Fig. 5c; Dini 1997). The sanidine megacrysts in the older San Martino porphyry have essentially identical characteristics, but lack poikilitic overgrowths.

Matrix phases of the Monte Capanne pluton are dominated by sub- to euhedral plagioclase $(2-10 \mathrm{~mm})$, zoned from cores of $\mathrm{An}_{40-45}$ to rims of $\mathrm{An}_{20-12}$. Most quartz (2-4 mm) occurs interstitially with only scattered euhedral phenocrysts $(\leq 1 \mathrm{~cm})$. Interstitial untwinned matrix K-feldspar is anhedral $(0.5-0.8$ $\mathrm{cm})$. Biotite is the only significant ferromagnesian mineral in 


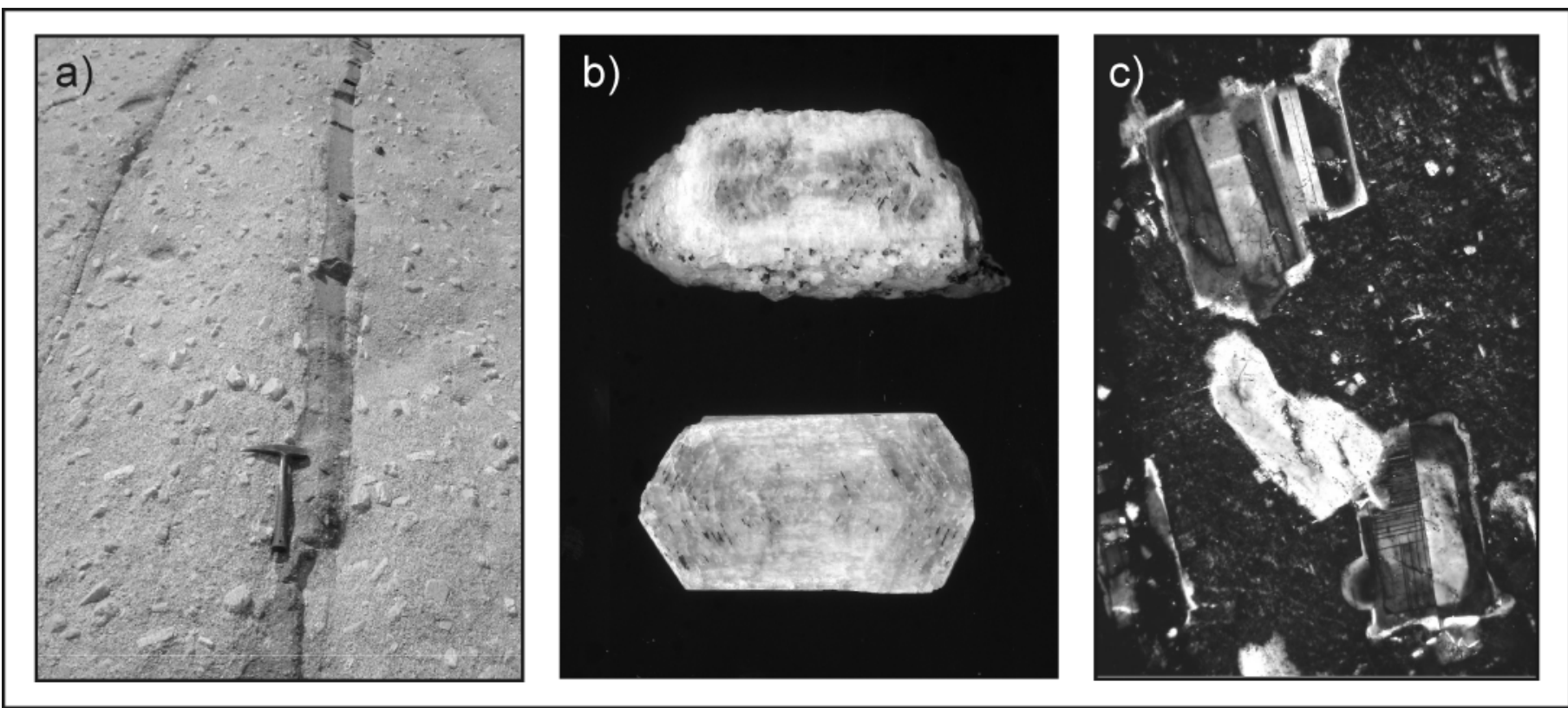

Fig. 5 Monte Capanne K-feldspar megacrysts: a) Sant'Andrea facies cut by Orano dyke with K-feldspar xenocrysts, b) hourglass zoning (crystals $10 \mathrm{~cm}$ long), and c) concentrically zoned plagioclase inclusions (crystals $0.1 \mathrm{~mm}$ long).

the Monte Capanne pluton, occurring as $2-3 \mathrm{~mm}$ crystals in the matrix with $\mathrm{Mg} \#=0.50$ (Bussy 1990 ) and $\mathrm{Rb} / \mathrm{Sr}=80-150$ (Juteau et al. 1984). Accessory minerals include apatite, zircon, monazite, tourmaline, allanite, and ilmenite.

The two extreme facies of the pluton are easily distinguished by their textures. The Sant'Andrea facies exhibits high percentages of coarse phenocrysts (Kfs, Qz, Bt) with about 150-200 Kfs crystals $/ \mathrm{m}^{2}$ (max. 300/ $\mathrm{m}^{2} ; ~ 30$ vol\%), and high densities of complex mafic microgranular enclaves. In contrast, the San Piero facies appears primarily in the southeastern quarter of the pluton, mostly as a homogeneous, fine- to medium-grained rock with only minor occurrence of the typical K-feldspar megacrysts. However in this facies, K-feldspar developed as a late phase that occurs as large K-feldspar plates in normal abundance (10-20\%), commonly anhedral to subhedral and wholly poikilitic to the point of being nearly invisible unless seen as a reflecting cleavage surface. This same texture also occurs as overgrowths on normal megacrysts. Additionally, the San Piero facies has a distinct paucity of microgranular mafic enclaves. The distinction of the San Piero facies as a petrographic subdivision of the pluton is supported by structural studies (Boccaletti and Papini 1989) that identified a strong NNE-SSW preferred orientation of minerals in the southeastern region, in contrast with the more irregular fabrics found in the northwestern part of the pluton. This pattern is mimicked by those derived from AMS data (Bouillin et al. 1993).

Mineralogical distinctions between the facies (Dini et al. 2002) also include the presence, in only the San Piero and San Francesco facies, of plagioclase with core compositions up to $\mathrm{An}_{45}$ and the common occurrence of amphibole clots replacing former pyroxenes. These facies differ further from the Sant'Andrea facies in that they display two distinct reaction microtextures involving minerals of the monazite group
(Type I and Type II; Dini et al. 2004). Type-I texture (Fig. 6a) is represented by aggregates of allanite-(Ce) and minor apatite replacing, to different degrees, original euhedral monazite-(Ce) crystals which remain as skeletal relics. Type-II texture (Fig. 6b) is represented by clusters $(50-100 \mu \mathrm{m})$ of Th-rich monazite microcrystals $(1-10 \mu \mathrm{m})$ pointing out the former presence of a euhedral prismatic crystal of an unknown mineral. The space between the Th-rich (huttonitic) monazite microcrystals is filled by interstitial quartz and K-feldspar, plus some anhedral grains of apatite. These two reaction microtextures are accompanied by stable euhedral monazite that is scattered throughout all the facies of the pluton and represents the main LREE reservoir in the Monte Capanne pluton.

A fourth facies of the pluton, the Punta del Cotoncello facies, occurs only locally where it cuts the Sant'Andrea facies as a $500 \mathrm{~m}$ long dyke, with modest concentration of K-feldspar megacrysts, an absence of microgranular enclaves, and a distinctly finer matrix than is typical for the Monte Capanne pluton. Textural evidence of mingling increases toward the east where the dyke thins, indicating that Cotoncello magma coexisted with the host, while at the same time, the host was intruded by a dyke.

As noted above, characteristic of the Monte Capanne pluton is the presence of mafic microgranular enclaves in varying amounts and sizes, being generally less abundant in the southeastern portion of the pluton. These enclaves also vary in composition from tonalite to monzogranite (Fig. 3), and consist principally of fine-grained plagioclase laths and biotite with varying quantities of generally rounded and resorbed xenocrysts of K-feldspar and quartz; textures include doleritic, ophitic, and microgranular (Fig. 7a; Bussy 1990; Bussy 1991; Poli and Tommasini 1991). Rare pyroxene crystals are observed, but patches of fibrous amphibole replacing pyrox- 


\section{Type I reaction}

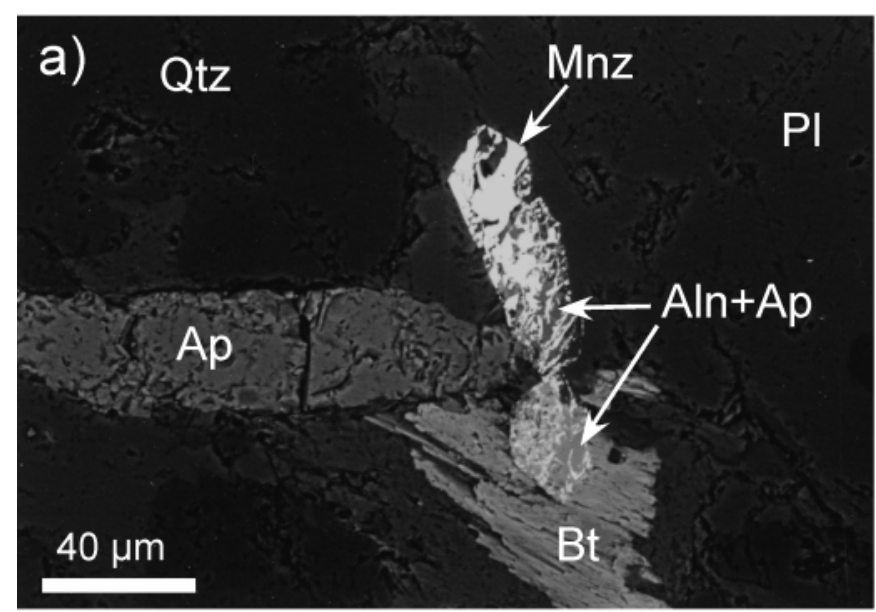

monazite-(Ce) from the melt

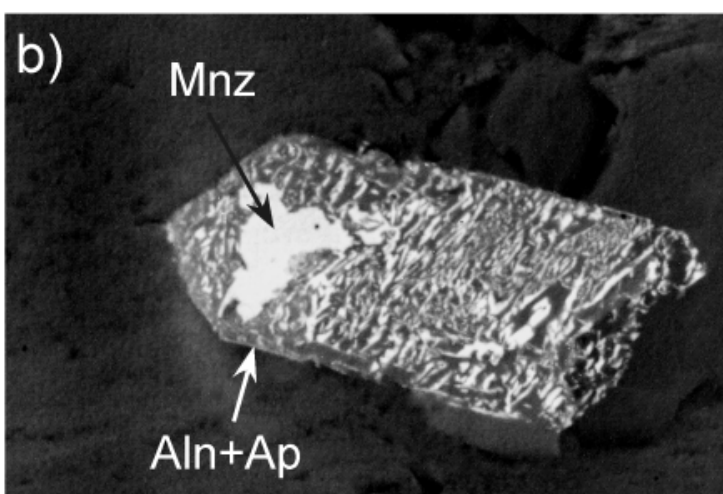

Bt

$15 \mu \mathrm{m}$

\section{allanite- $(\mathrm{Ce})$}

(Decreasing $\mathrm{ASI}$ - increasing $\mathrm{Ca}$ activity in the melt)

\section{Type II reaction}
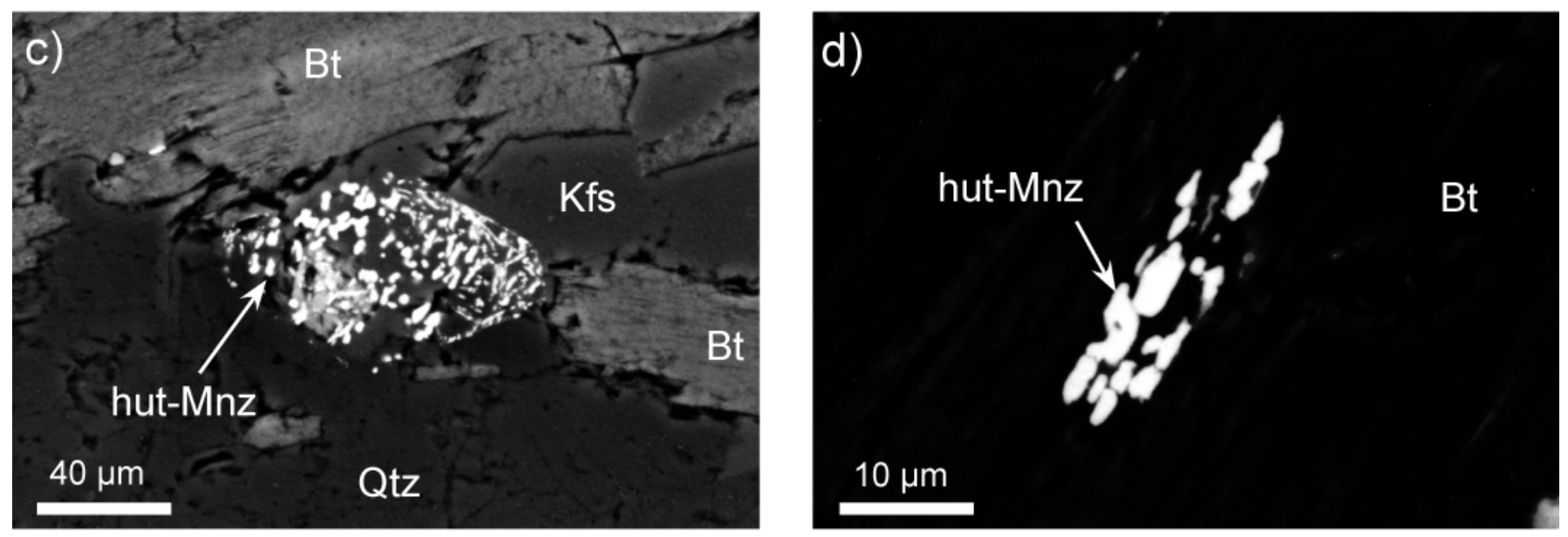

$$
\begin{array}{cccc}
\text { apatite } & \text { from the melt } & \text { huttonic monazite the melt } & \text { to the } \\
(\mathrm{Ca}, \mathrm{LREE})_{5}\left(\mathrm{PO}_{4}\right)_{3}(\mathrm{~F}, \mathrm{OH})+\left(\mathrm{Al}_{2} \mathrm{O}_{3}+\mathrm{SiO}_{2}\right) \Leftrightarrow & (\mathrm{LREE}, \mathrm{Th})\left(\mathrm{PO}_{4}\right)\left(\mathrm{SiO}_{4}\right)+\left(\mathrm{CaO}+\mathrm{AlPO}_{4}+\mathrm{F}+\mathrm{H}_{2} \mathrm{O}\right) \\
& (\text { Increasing } \mathrm{ASI}-\text { decreasing Ca activity in the melt })
\end{array}
$$

Fig. 6 Selected SEM-BSE images of accessory minerals of Monte Capanne pluton: a) Type-I reaction microtexture, and b) Type-II reaction microtexture. Abbreviations: Aln, allanite-(Ce); Ap, apatite; Bt, biotite; hut-Mnz, huttonitic monazite; Kfs, K-feldspar; Mnz, monazite-(Ce); Pl, plagioclase; Qtz, quartz.

ene are common. Multiple enclaves are quite common in the Monte Capanne system, always with the finer grained one contained within the coarser grained one, and typically with both enclaves containing xenocrysts (Fig. 7b). Also present as scattered inclusions throughout the pluton are aluminous restitic, characteristically biotite-rich xenoliths.

\section{Geochemistry}

The Monte Capanne pluton varies little in major element concentrations (Table 1). It is dominantly monzogranite $\left(\mathrm{SiO}_{2}\right.$ $\sim 66-70 \mathrm{wt} \%$ ) and is slightly peraluminous in character (aver- age $\mathrm{ASI}=1.11$ ). . However, variation diagrams for $\mathrm{MgO}$ vs. $\mathrm{SiO}_{2}$ and $\mathrm{Sr}$ vs. $\mathrm{SiO}_{2}$ (Fig. 8) illustrate the more evolved character of the Sant'Andrea facies relative to the less evolved San Piero facies. The intrusive units of the pre-pluton laccolith complex are more acidic than the pluton, whereas the mafic microgranular enclaves are generally less acidic $\left(\mathrm{SiO}_{2}\right.$ from 61.5 to 68.3 wt $\%$; Fig. 3). All of these rocks are peraluminous and contain normative corundum, except for the most mafic enclaves.

The most felsic products associated with the pluton are chemically distinct from the main facies and from each other, whereas the Cotoncello dyke (ASI $=1.16$ ) has the highest combined alkali concentration of the Monte Capanne units 

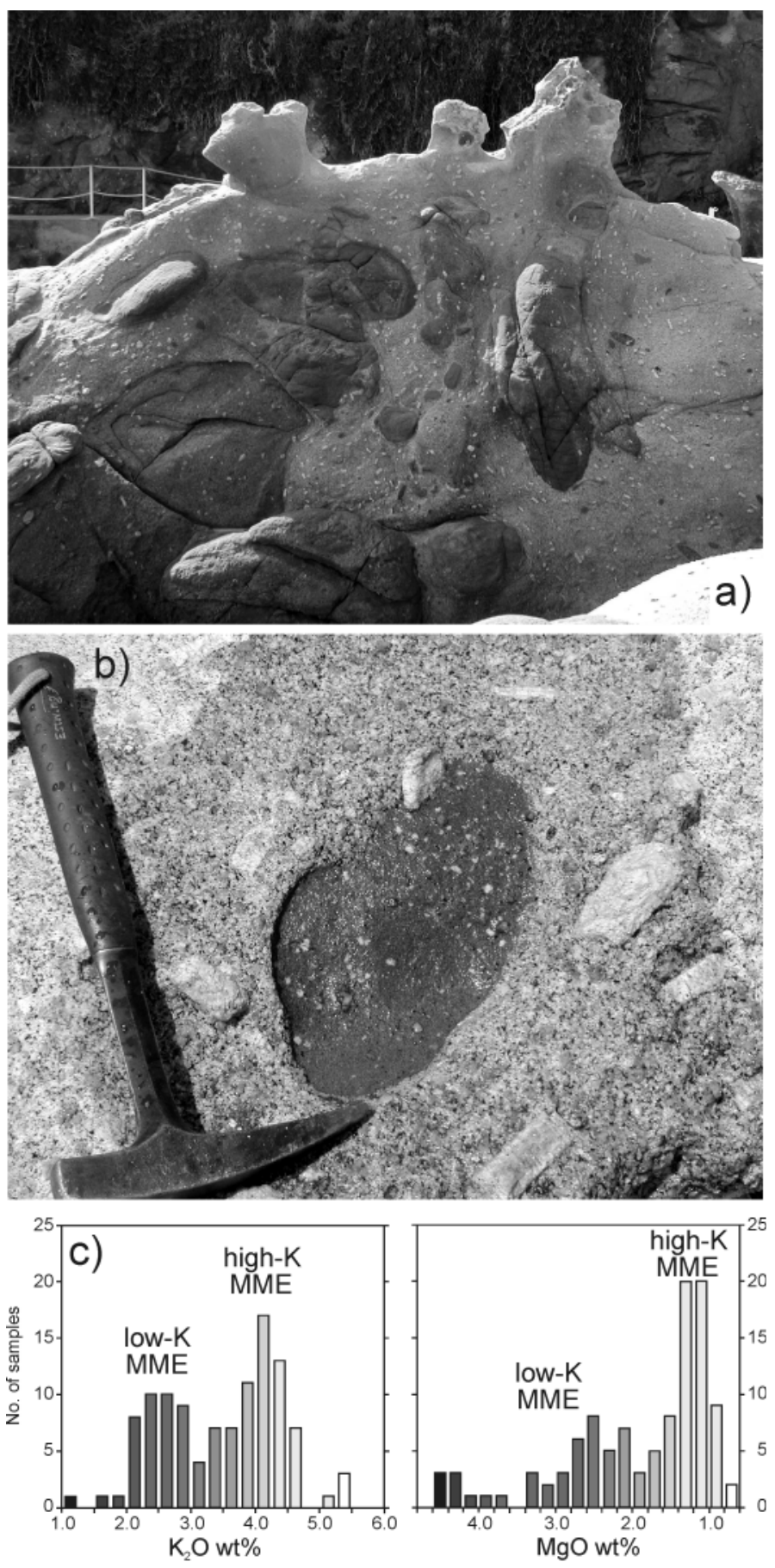

Fig. 7 Monte Capanne mafic microgranular enclaves at Sant'Andrea: a) compositionally variable, single, and composite enclaves with abundant xenocrysts, and b) a composite enclave with a partially captured K-feldspar megacryst and abundant smaller xenocrysts. Note the sharp contrast in xenocryst content of the more mafic internal enclave. Diagram c) shows histograms for $\mathrm{K}_{2} \mathrm{O}$ and $\mathrm{MgO}$ of 110 enclaves from (Bussy 1990; Dini et al. 2002), and unpublished work by the authors.
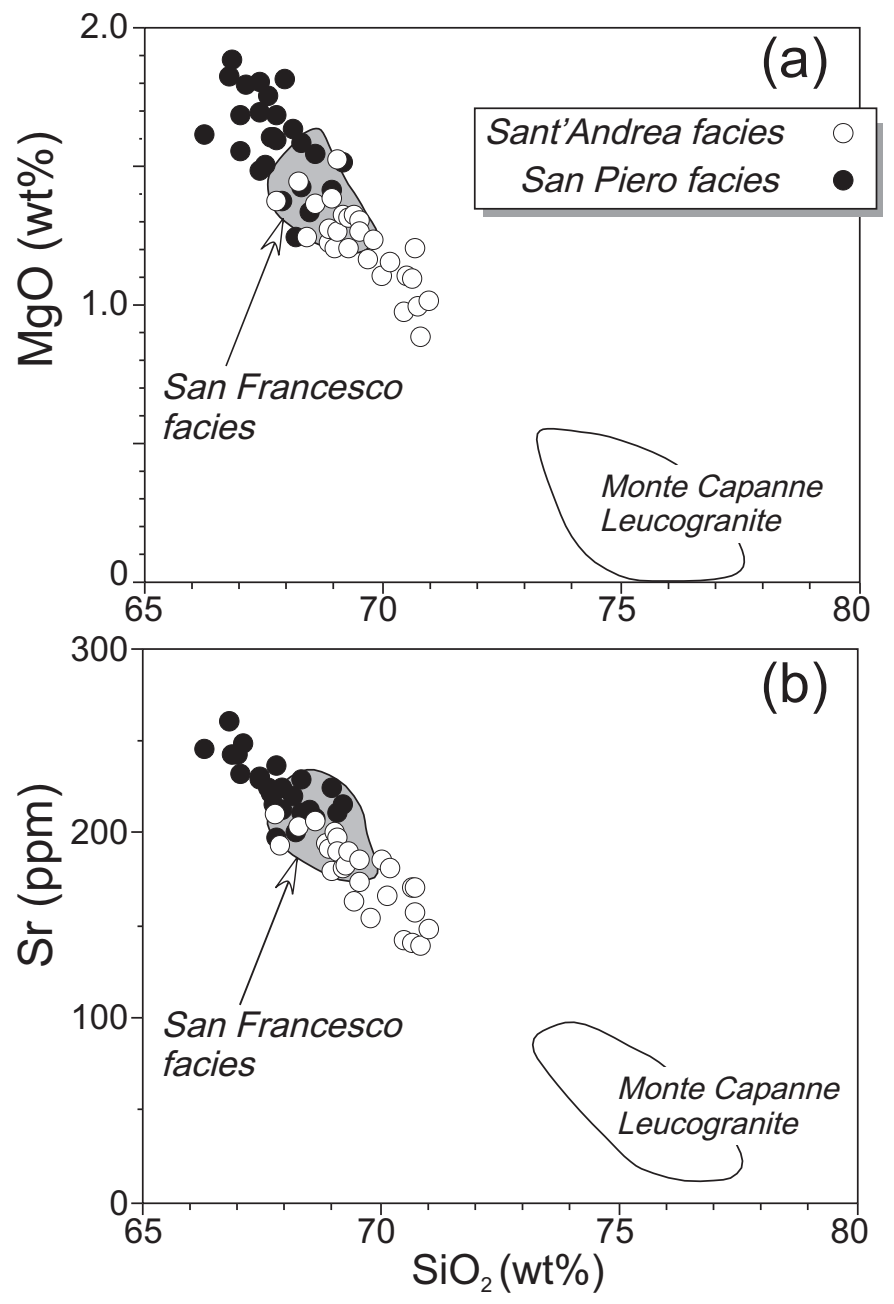

Fig. 8 Harker diagrams for $\mathrm{MgO}$ and Sr illustrating general chemical distinctions between facies. Data are from Bussy 1990; Dini et al. (2002), and unpublished work by the authors.

Table 1. Average major element chemical compositions for late Miocene intrusive units from Elba Island

\begin{tabular}{|c|c|c|c|c|c|c|c|c|c|}
\hline \multirow[b]{2}{*}{ Unit } & \multirow[b]{2}{*}{ 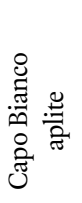 } & \multirow[b]{2}{*}{ 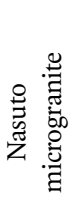 } & \multicolumn{7}{|c|}{ Monte Capanne pluton } \\
\hline & & & 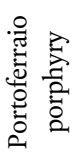 & 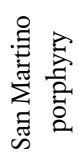 & & 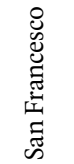 & 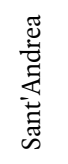 & 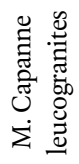 & 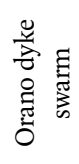 \\
\hline $\mathrm{SiO}_{2}$ & 73.07 & 69.10 & 69.92 & 68.78 & 66.99 & 67.90 & 69.06 & 74.38 & 65.08 \\
\hline $\mathrm{TiO}_{2}$ & 0.02 & 0.36 & 0.29 & 0.36 & 0.53 & 0.51 & 0.45 & 0.17 & 0.60 \\
\hline $\mathrm{Al}_{2} \mathrm{O}_{3}$ & 16.59 & 16.45 & 15.82 & 16.28 & 15.87 & 15.71 & 15.40 & 14.09 & 15.76 \\
\hline $\mathrm{Fe}_{2} \mathrm{O}_{3}$ & 0.23 & 0.40 & 0.50 & 0.52 & 1.60 & 1.16 & 0.96 & 0.53 & 1.08 \\
\hline $\mathrm{FeO}$ & 0.23 & 1.54 & 1.24 & 1.56 & 1.68 & 1.86 & 1.72 & 0.49 & 2.74 \\
\hline $\mathrm{MnO}$ & 0.05 & 0.04 & 0.03 & 0.04 & 0.05 & 0.05 & 0.05 & 0.03 & 0.06 \\
\hline $\mathrm{MgO}$ & 0.09 & 0.99 & 0.85 & 0.94 & 1.57 & 1.33 & 1.10 & 0.36 & 2.62 \\
\hline $\mathrm{CaO}$ & 0.22 & 0.83 & 1.57 & 2.11 & 2.85 & 2.63 & 2.30 & 0.94 & 3.15 \\
\hline $\mathrm{Na}_{2} \mathrm{O}$ & 4.24 & 3.82 & 3.60 & 3.38 & 3.26 & 3.39 & 3.27 & 3.20 & 3.22 \\
\hline $\mathrm{K}_{2} \mathrm{O}$ & 4.06 & 4.71 & 4.50 & 4.23 & 4.23 & 4.19 & 4.37 & 5.07 & 3.65 \\
\hline $\mathrm{P}_{2} \mathrm{O}_{5}$ & 0.02 & 0.06 & 0.10 & 0.14 & 0.22 & 0.19 & 0.17 & 0.06 & 0.19 \\
\hline LOI & 1.2 & 1.69 & 1.60 & 1.99 & 0.88 & 0.82 & 0.84 & 0.68 & 1.75 \\
\hline ASI & 1.42 & 1.29 & 1.18 & 1.22 & 1.05 & 1.06 & 1.08 & 1.15 & 1.09 \\
\hline
\end{tabular}

Abbreviation: ASI: Alumina Saturation Index, corrected for the apatite content. 
Table 2. Sr isotopic data for K-feldspar megacrysts, biotite inclusions in megacrysts, phenocryst minerals, and whole rock samples from some intrusive units from Elba and Montecristo Island

\begin{tabular}{lccccccc}
\hline \multicolumn{1}{c}{ unit and } & description & $\begin{array}{c}\mathrm{Sr} \\
\text { sample }\end{array}$ & $\begin{array}{c}\mathrm{Rb} \\
(\mathrm{ppm})\end{array}$ & $\begin{array}{c}{ }^{87} \mathrm{Sr} /{ }^{86} \mathrm{Sr} \\
(\mathrm{m})\end{array}$ & $2 \sigma$ & ${ }^{87} \mathrm{Rb} /{ }^{86} \mathrm{Sr}$ & $\begin{array}{c}{ }^{87} \mathrm{Sr} /{ }^{86} \mathrm{Sr} \\
(\mathrm{t})\end{array}$ \\
\hline \multicolumn{2}{c}{ San Martino Porphyry-(7.2 Ma) } & & & & & & \\
PP118-MKfs/1 & composite 1 & 446.5 & 299.4 & 0.71801 & \pm 7 & 4.32 & 0.71757 \\
PP118-Mkfs/2 & composite 2 & 476.0 & 297.0 & 0.71776 & \pm 3 & 4.64 & 0.71729 \\
PP118-Mkfs/3 & composite 3 & 488.9 & 304.0 & 0.71766 & \pm 2 & 4.66 & 0.71718 \\
PP118-MBt/2 & from composite 2 & 1066.0 & 4.4 & 0.78483 & \pm 6 & 711.10 & 0.71212 \\
PP118-Pl & phenocrysts & 94.8 & 350.0 & 0.71637 & \pm 3 & 0.78 & 0.71629 \\
PP118-Bt & phenocrysts & 851.0 & 7.2 & 0.75101 & \pm 7 & 341.52 & 0.71609 \\
PP118-wr & - & 301.0 & 173.1 & 0.71668 & \pm 8 & 5.04 & 0.71617 \\
Orano Porphyry - (6.85 Ma) & & & & & & \\
PP212-Mkfs/1 & composite 1 & 374.0 & 393.0 & 0.71496 & \pm 5 & 2.76 & 0.71469 \\
PP212-Mkfs/2 & composite 2 & 373.0 & 391.0 & 0.71488 & \pm 2 & 2.76 & 0.71461 \\
PP212-Mkfs/3 & composite 3 & 384.0 & 396.0 & 0.71512 & \pm 8 & 2.81 & 0.71485 \\
PP212-MBt/1 & from composite 2 & 868.0 & 8.4 & 0.74258 & \pm 4 & 298.57 & 0.71333 \\
Montecristo Pluton - (7.07 Ma) & & & & & & \\
MW27-Mkfs/1a & core & 543.0 & 159.0 & 0.71785 & \pm 7 & 9.89 & 0.71685 \\
MW27-Mkfs/1b & rim & 580.0 & 146.0 & 0.71665 & \pm 4 & 11.52 & 0.71548 \\
MW27-Kfs & matrix-interstitial & 602.0 & 111.0 & 0.71604 & \pm 3 & 15.70 & 0.71446 \\
MW27-Plg & matrix-subhedral & 66.9 & 216.0 & 0.71482 & \pm 4 & 0.90 & 0.71473 \\
MW27-Bt & matrix-subhedral & 1652.0 & 1.7 & 1.00343 & \pm 6 & 2876.05 & 0.71468 \\
MW27-wr & - & 382.0 & 111.0 & 0.71566 & \pm 4 & 9.96 & 0.71466 \\
\hline
\end{tabular}

Abbreviations: Kfs: K-feldspar, MKfs: Kfs megacryst, MBt: biotite inclusions in MKfs, Bt: biotite, Pl: plagioclase, wr: whole rock.

(Fig. 3). In contrast, the leucogranite dykes have the highest $\mathrm{SiO}_{2}$ (and lowest $\mathrm{MgO}$ ) contents of the analyzed rocks from the Elba magmatic complex, and plot as an extension of the Monte Capanne pluton field. Compositions of the monzogranitic Orano dyke samples plot with samples of the Monte Capanne pluton, whereas the granodioritic Orano group plot separately (Fig. 3). The xenocryst-rich Orano rocks are interpreted as mixtures of hybrid Orano magma and phases from the Monte Capanne system.

Trace element and REE distributions for rocks of the Monte Capanne pluton (not illustrated) have been compared to those of the other Elba magmatic products (Dini et al. 2002). Based on that work, it can be shown that the Monte Capanne pluton has i) low variability in trace element concentrations and ii) a homogeneous REE distribution throughout the pluton. The San Martino porphyry, as well as its enclosed mafic microgranular enclaves, shows patterns nearly identical to those of the Monte Capanne pluton, but absolute concentrations are slightly lower for the porphyry and higher for the enclaves with respect to the pluton. Among the late felsic facies associated with the Monte Capanne pluton, the Cotoncello dyke is more fractionated than the Monte Capanne rocks.

A limited but detailed study of K-feldspar megacrysts from rocks related to the Monte Capanne pluton indicates marked variation in ${ }^{87} \mathrm{Sr} /{ }^{86} \mathrm{Sr}$ ratios of included biotites compared to their K-feldspar megacryst host, and to the matrix biotite of the enclosing rock (Table 2). Samples for biotite inclusion analysis are a megacryst from the San Martino laccolith and a xenocryst from an Orano dyke; the xenocryst is presumed to have been captured from the partially molten Monte Capanne pluton that the dyke intruded. Additional data are reported for K-feldspar megacryst and phenocryst/matrix phases from another 7 Ma TMP pluton, the Montecristo monzogranite. The biotite inclusions have low initial ${ }^{87} \mathrm{Sr} /{ }^{86} \mathrm{Sr}$ ratios $(<0.7127)$, their host K-feldspars have high ratios ( $>0.7174)$, and biotite and plagioclase in the matrix have slightly reduced ${ }^{87} \mathrm{Sr} /{ }^{86} \mathrm{Sr}$ ratios ( 0.7163), all corrected to their radiometric ages (Dini $e t$ al. 2002; Innocenti et al. 1997). These values are illustrated in Fig. 9a with ${ }^{87} \mathrm{Sr} /{ }^{86} \mathrm{Sr}$ ratios plotted against approximated time in the crystallization sequence as constrained by petrography. Additionally, the $\mathrm{Rb} / \mathrm{Sr}$ ratio for included biotite is 244 vs. 80-150 for associated biotite phenocrysts.

The extent of hybridization of rocks from the Monte Capanne pluton is well illustrated using a ${ }^{143} \mathrm{Nd} /{ }^{144} \mathrm{Nd}$ vs. ${ }^{87} \mathrm{Sr} /$ ${ }^{86} \mathrm{Sr}$ diagram (Fig. 10) where they are seen in relation to other units of the TMP. Samples from the Monte Capanne main facies plot near the center of the figure in a restricted field. Their compositions fall along a mixing curve that connects San Vincenzo rhyolite and Cotoncello dyke (best representatives of the crustal melt product for the system), to the San Vincenzo 

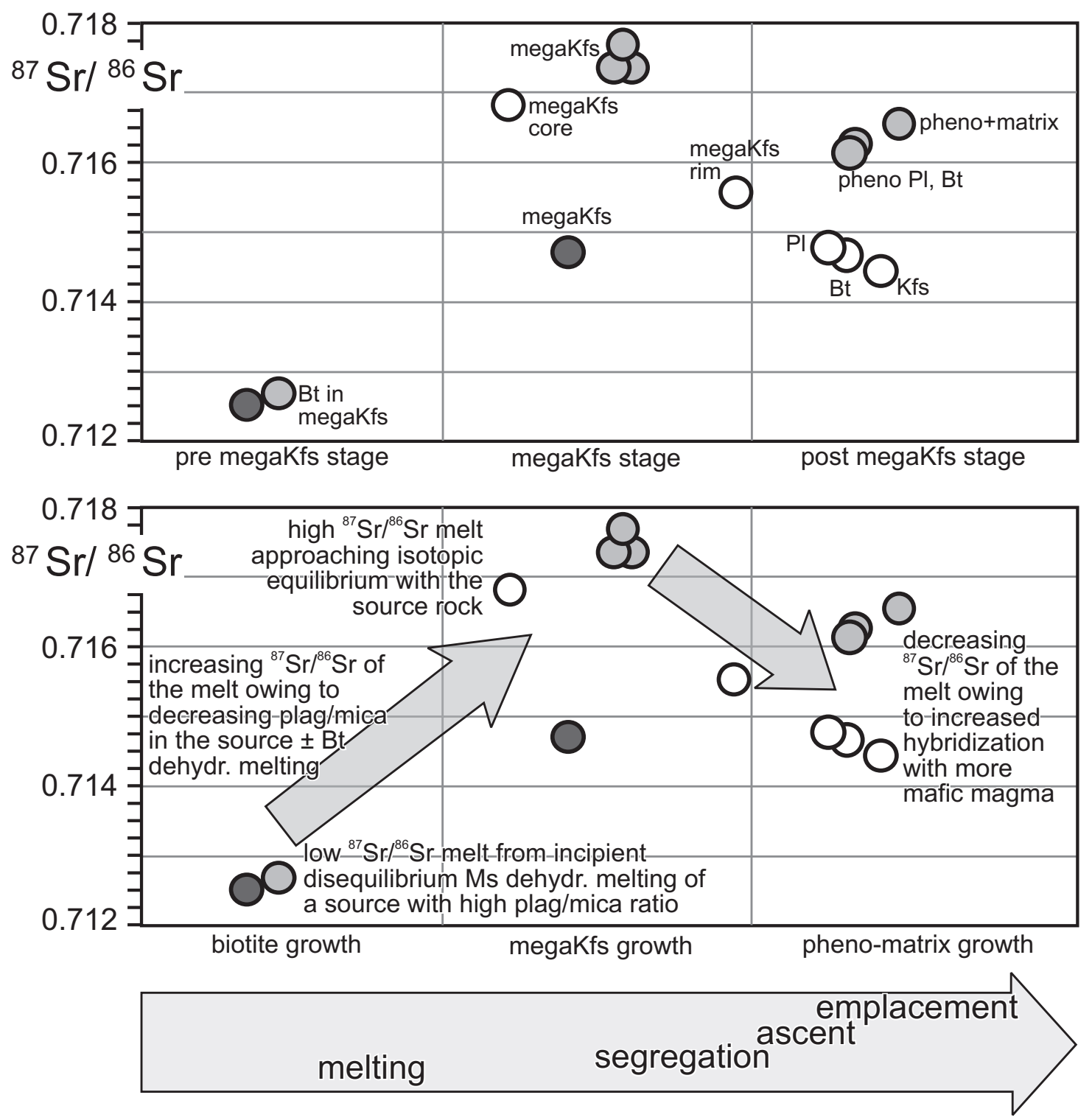

Fig. 9 Plot of ${ }^{87} \mathrm{Sr} /{ }^{86} \mathrm{Sr}$ vs. "time" based on petrogenetic occurrence of the phases: a) mineral data and b) a ${ }^{87} \mathrm{Sr} /{ }^{86} \mathrm{Sr}$ vs. "time" model; white-filled dots - San Martino laccolith, light grey dots - Montecristo monzogranite, dark grey dots - Orano porphyry.

enclaves and Capraia K-andesites (best representatives of the mafic end of the series).

Also illustrated in Fig. 10 are the high ${ }^{87} \mathrm{Sr} /{ }^{86} \mathrm{Sr}$ and low ${ }^{143} \mathrm{Nd} /{ }^{144} \mathrm{Nd}$ ratios of the Elba enclaves (Dini et al. 2002) in relation to others in the TMP, which suggest that they, too, have experienced extensive hybridization. Recent data on a Monte Capanne enclave also shows similar ${ }^{87} \mathrm{Sr} /{ }^{86} \mathrm{Sr}$ ratios (<0.712; (Poli et al. 2002). Although this range of hybridization is significant ( 0.7 to $4.5 \mathrm{wt} \% \mathrm{MgO}$, and 1.13 to $5.38 \mathrm{wt} \% \mathrm{~K}_{2} \mathrm{O}$ ), compositions are clearly bimodal with a significant intermediate population (Fig. 7c).

\section{DISCUSSION}

Petrographic and geochemical characteristics of the Monte Capanne magmatic system, as discussed below, indicate it was evolving long before it reached its emplacement level where the rocks are currently exposed. However, questions remain as to where and to what extent this evolution occurred. Insights should come from materials in the rocks that existed over the longest part of the pluton's history, and potential candidates include the complex K-feldspar megacrysts, the early accessory mineral assemblage, and the mafic microgranular enclaves. 


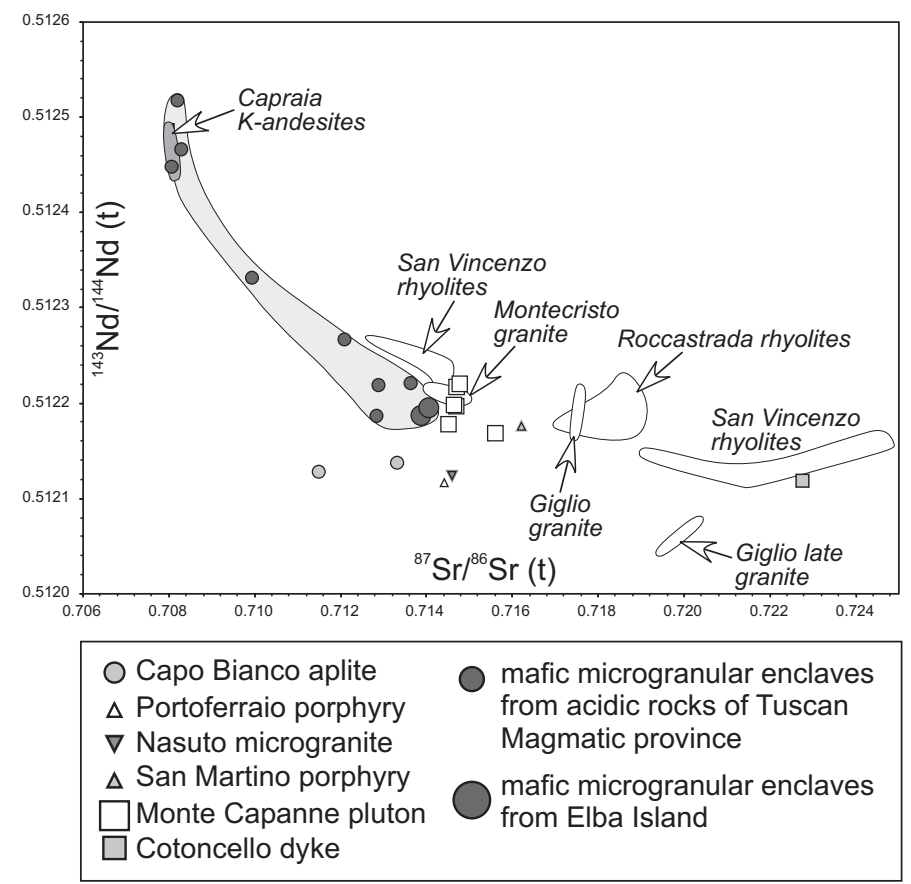

Fig. 10 Initial ${ }^{143} \mathrm{Nd} /{ }^{144} \mathrm{Nd}$ vs. ${ }^{87} \mathrm{Sr} /{ }^{86} \mathrm{Sr}$ plot for selected igneous samples from the Tuscan Magmatic Province. Modified after Dini et al. (2002).

\section{K-feldspar megacrysts}

A magmatic origin for the ubiquitous K-feldspar megacrysts of the Monte Capanne pluton and many of the other TMP units is supported by the pertinent criteria detailed by Vernon and Paterson (Vernon and Paterson 2002), as well as by the earlier work of Vernon (1986). In addition, K-feldspar megacrysts from the San Martino laccolith, whose size, internal texture, and composition are similar to those from the Monte Capanne pluton, preserve a high-T structural state (sanidine): this observation lends further support to their igneous origin. However, the time and location of their formation must be considered. Poikilitic overgrowths containing the matrix assemblage characterize many of these megacrysts, and locally they exhibit flow alignment (Boccaletti and Papini 1989), both suggesting formation of the megacrysts prior to emplacement. Additionally, the Monte Capanne pluton was emplaced at the level of the deepest feeder dykes of the San Marino porphyry with its perfectly euhedral megacrysts (also often aligned by flow) suspended in an aphanitic matrix. Internal zoning and inclusion patterns are essentially identical for megacrysts from both units, and as the San Martino megacrysts obviously formed at a depth below Monte Capanne emplacement, it is logical to conclude that the Monte Capanne megacrysts did as well.

The biotite and plagioclase included in the Monte Capanne K-feldspar megacrysts apparently formed prior to the onset of megacryst growth rather than concurrently. These euhedral and minute inclusions are preferentially oriented and distributed to define an hourglass structure (best developed in the megacryst cores). Although these relationships by themselves are compatible with concurrent growth, the plagioclase crystals are concentrically zoned with oscillatory structures (Fig. 5c), requiring development of that zoning prior to inclusion in the growing K-feldspar crystal.

Data for ${ }^{87} \mathrm{Sr} /{ }^{86} \mathrm{Sr}$ ratios of K-feldspar megacrysts comes from three sources apparently disconnected from the Monte Capanne pluton itself; however, all of the data are from rocks genetically linked to the Monte Capanne system and can potentially provide insight into its evolution. One data set comes from the San Martino porphyry that formed by hybridization of two magmas from the same sources as the Monte Capanne pluton (Dini et al. 2002). A second data set comes from a xenocryst in the Orano porphyry, a unit characterized by extensive captured crystals from the Monte Capanne system (Dini et al. 2002). The third data set comes from the Montecristo pluton, a megacrystic Tuscan Magmatic pluton with petrogenesis, geochemistry, and age nearly identical to the Monte Capanne pluton (Innocenti et al. 1997), and those data are included because they exhibit the same pattern for megacrysts and later mineral phases.

The low ${ }^{87} \mathrm{Sr} /{ }^{86} \mathrm{Sr}$ ratios of included biotite grains, compared to high values for their K-feldspar megacryst host (Fig. 9a), strongly suggest geochemical evolution of the melt over time. This change, however, is not the result of modifying a felsic magma by addition of more mafic material like that available in the TMP (Fig. 10), because the result would be to lower the ${ }^{87} \mathrm{Sr} /{ }^{86} \mathrm{Sr}$ ratio of the system. Alternatively, we can consider the possibility that K-feldspar megacrysts grew in a fractionated product of a mafic magma that contained minute crystals of biotite, plagioclase, and quartz, but later was contaminated by a more felsic melt having a higher ${ }^{87} \mathrm{Sr} /{ }^{86} \mathrm{Sr}$ ratio. This process would require a very high degree of fractionation of the mafic magma in order to explain the rather low $\mathrm{Mg} \#$ of biotite inclusions, the acidic compositions of plagioclase inclusions, and the absence of amphibole in the assemblage of included phases.

An alternative explanation for the progressive increase in ${ }^{87} \mathrm{Sr} /{ }^{86} \mathrm{Sr}$ ratio is to start by muscovite dehydration melting with accompanying crystal growth of biotite and plagioclase. A system involving advective heating from intrusion of mafic melts can cause sufficiently rapid heating to preserve disequilibrium (Huppert and Sparks 1988), and melting can proceed rapidly once temperature overstep for the reaction occurs (Harris et al. 2000). Such conditions would produce an initial melt with a ${ }^{87} \mathrm{Sr} /{ }^{86} \mathrm{Sr}$ ratio reflective of the proportions of the phases involved in melting. Due to the high concentration of non-radiogenic $\mathrm{Sr}$ in the plagioclase consumed during the dehydration melting of muscovite, the ${ }^{87} \mathrm{Sr} /{ }^{86} \mathrm{Sr}$ ratio of the melt would probably be lower than that of the source (Knesel and Davidson 2002). A dropping feldspar-to-mica ratio, and the likely onset of biotite dehydration melting as temperatures continued to rise, would result in an increased ${ }^{87} \mathrm{Sr} /{ }^{86} \mathrm{Sr}$ ratio of the melt. Therefore, subsequent growth of K-feldspar megacrysts would have higher ${ }^{87} \mathrm{Sr} /{ }^{86} \mathrm{Sr}$ ratios than developed in the early-formed biotite. At a realistic pressure of 0.6-0.7 GPa at the base of the Tuscan crust, with its thickness of approximately 


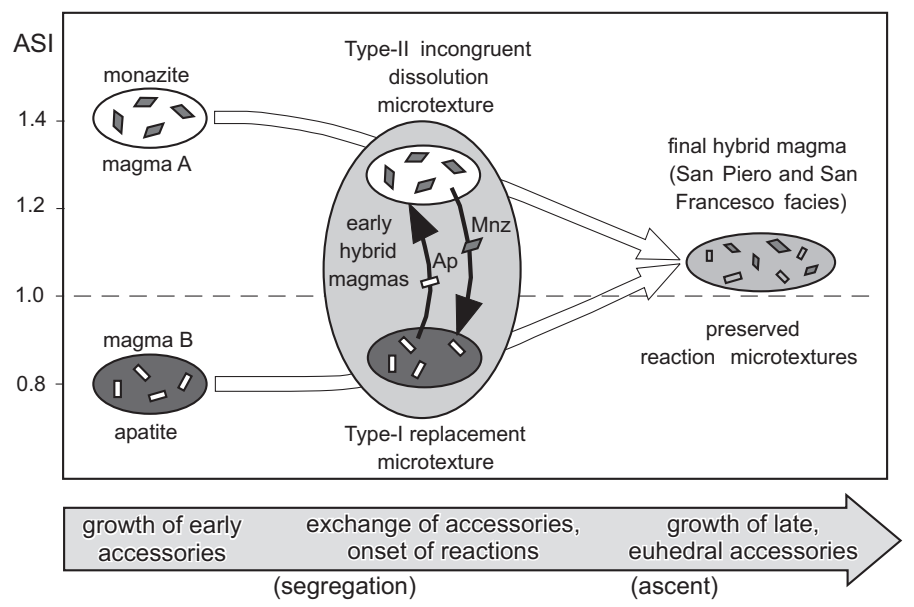

Fig. 11 Model for development of Type-I and Type-II reaction microtextures.

$25 \mathrm{~km}$ (Nicolich 2001), muscovite reactions would occur at approximately $725^{\circ}$ to $750^{\circ} \mathrm{C}$, about $50^{\circ}$ to $150^{\circ} \mathrm{C}$ below the biotite dehydration reactions (Patiño Douce 1999).

Biotite and plagioclase occurring as phenocrysts and in the matrix associated with analyzed K-feldspar megacrysts (Table 2) have intermediate ${ }^{87} \mathrm{Sr} /{ }^{86} \mathrm{Sr}$ ratios that require the melt to have evolved once again, but this time after the K-feldspar megacrysts had begun to form (Fig. 9a). These data show a consistent pattern of decreasing ${ }^{87} \mathrm{Sr} /{ }^{86} \mathrm{Sr}$ ratio from the time of K-feldspar megacryst growth to the time of matrix crystallization. Such a change would predictably occur if the crustal magma interacted with a more mafic magma having a lower ${ }^{87} \mathrm{Sr} /{ }^{86} \mathrm{Sr}$ ratio, a product readily available as witnessed by TMP enclave compositions (Fig. 10). Similar, although more complex, relationships are reported for feldspar phenocrysts that grew in a progressively hybridized granitic host before transfer to a mafic microgranular enclave where growth continued with reversing isotopic trends (Waight et al. 2000).

\section{Accessory minerals}

Additional evidence bearing on the evolution of the system comes from reaction microtextures of REE-Y-Th-U accessory minerals, most notably involving monazite in three distinct habits (Dini et al. 2004). Stable euhedral monazite-(Ce), a LREE-rich monazite with $\mathrm{Ce}$ as the dominant trivalent cation ( $\left.27 \mathrm{wt} . \% \mathrm{Ce}_{2} \mathrm{O}_{3}\right)$, occurs throughout the pluton. In addition, the intermediate San Francesco facies and the most hybridized San Piero facies also contains both Type-I microtextures with aggregates of allanite-(Ce) replacing original euhedral monazite-(Ce), and Type-II with Th-rich monazite ( $\left.38 \mathrm{wt} . \% \mathrm{ThO}_{2}\right)$ microcrystals as clusters replacing euhedral prismatic crystals of an unknown mineral (Fig. 6). The absence of hydrothermal alteration products and the presence of unaltered euhedral monazite indicate that these reactions are not post-magmatic in origin. At the other extreme, a restitic origin is ruled out by the general euhedral nature of the crystals involved. The hosting of the reaction texture minerals in the cores of early euhedral-subhedral biotite and plagioclase crystals argues for an early primary magmatic origin.

The stability of monazite-(Ce), allanite-(Ce), and apatite as accessory phases is mainly controlled by the activity of $\mathrm{Ca}$ and the degree of peraluminosity of the melt. Allanite-(Ce) (and/or titanite) should be stable in metaluminous melts with $\mathrm{CaO}>1 \mathrm{wt} \%$ (Cuney and Friedrich 1987); in contrast, monazite-(Ce) is a stable phase in peraluminous melts in which it has low solubility (Rapp and Watson 1986). Higher ASI values of melts increase the stability of the $\mathrm{AlPO}_{4}$ complex, which in turn, enhances the solubility of apatite (Wolf and London 1995). Thus, in a qualitative way, early crystallization of apatite and allanite-(Ce) (and/or titanite) is favoured in metaluminous melts, whereas early crystallization of monazite-(Ce) should occur in truly peraluminous melts (Fig. 12). However, an intermediate field of melt composition can be identified in which all the phases could coexist, represented by slightly peraluminous, hybrid granitoids that resemble the actual compositions in the Monte Capanne pluton. Therefore, the actual compositions of Monte Capanne products are compatible with the observed coexistence of monazite-(Ce), allanite-(Ce), and apatite, but cannot explain the reaction microtextures involving these minerals whose formation requires "extreme" melt compositions.

Dini et al. (2004) have argued that the simplest way to generate the coexisting Type I and Type II microtextures is to grow apatite in metaluminous magma while concurrently growing monazite-(Ce) in strongly peraluminous anatectic magma, all followed by a mingling/mixing history with crystal transfer between them before the melts reach chemical equilibrium (Fig. 12). The new extreme chemical conditions would have created destabilized apatite (strongly soluble in peraluminous melts) and monazite-(Ce) (strongly soluble in metaluminous melts) to produce the observed microtextures. Continued interaction of the two magmas, primarily during the dynamic melt segregation and ascent phases of the system, would produce a hybrid product in which all phases were stable, much like that represented by the San Francesco and San Piero facies of the Monte Capanne pluton.

\section{Mafic microgranular enclaves}

Mafic microgranular enclaves in both the Monte Capanne pluton and the San Martino porphyry, including multiple enclaves, characteristically contain xenocrysts in various stages of "capture" (Fig. 7b; Bussy 1991). The crystal transfer implies relative movement between enclaves and phenocrysts probably occurring during the ascent of the entire system. Uncertainty remains, however, about when and where these textures developed.

Mafic microgranular enclaves characteristically occur with a medium-grained texture (microgranular), entirely independent of the texture of their plutonic, subvolcanic or volcanic host. It is reasonable to conclude that in the case of the San Martino porphyry with its aphanitic matrix, the coarser grain 


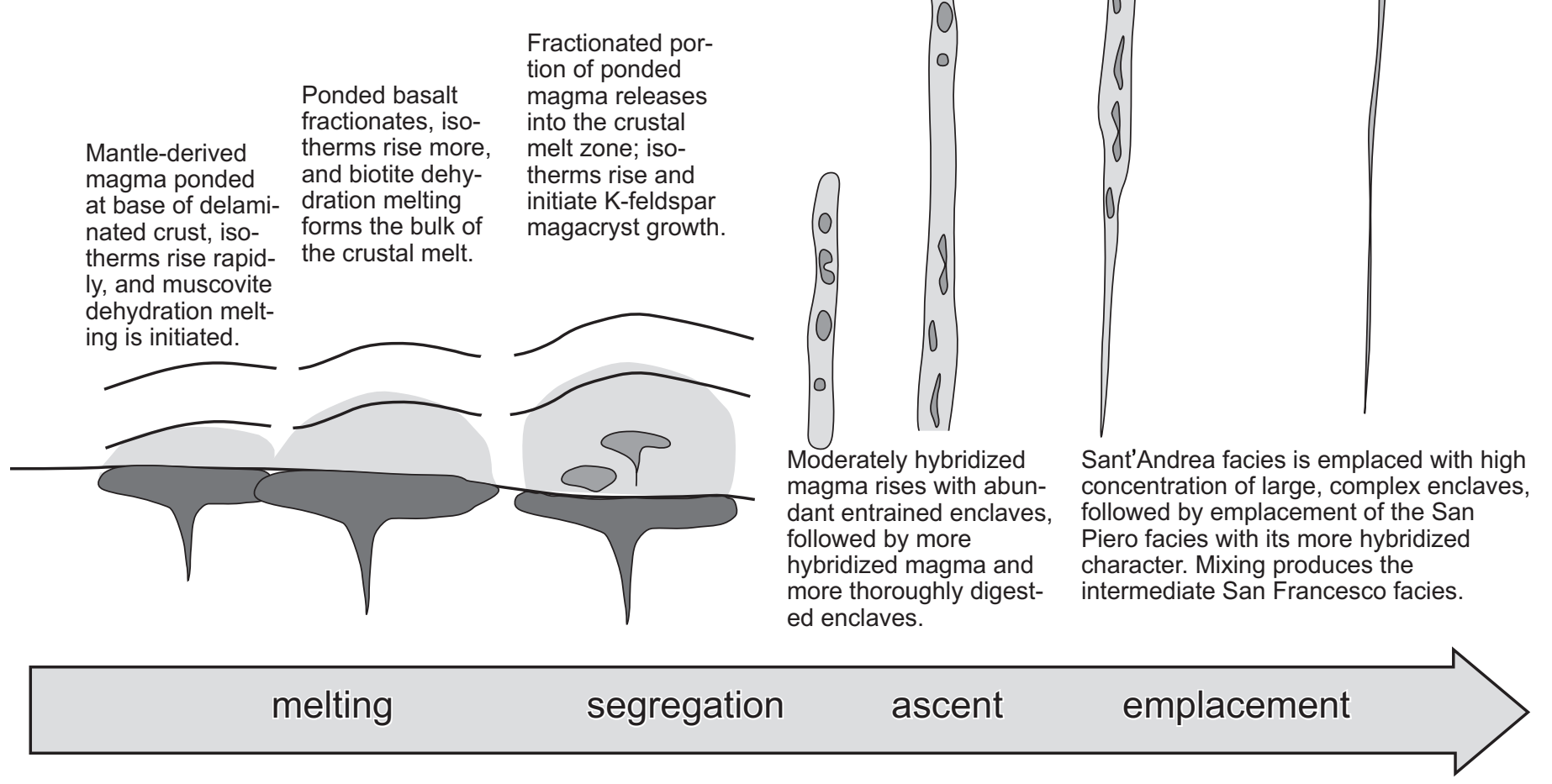

Fig. 12 Melting-segregation-ascent-emplacement (MSAE) model for the Monte Capanne pluton.

size of the more mafic enclaves suggests that they arrived as solids or near-solids (crystal mushes) rather than crystallizing after emplacement even at the level of the deepest feeder dykes. The Monte Capanne pluton was emplaced at that same level, and its enclaves also display textures out of equilibrium with their coarser-grained host, suggesting that they, too, arrived almost crystallized. In both cases, the enclaves commonly contain K-feldspar megacrysts that would have to have formed earlier (and deeper) in order to allow their transfer to the more mafic magma. The presence of abundant xenocrysts (not only of K-feldspar) in many of the mafic microgranular enclaves indicates that crystal transfer was a significant hybridization mechanism contributing to the broad range of enclave compositions. Based on these arguments, the timing of hybridization of the Monte Capanne pluton is constrained to have occurred prior to reaching its emplacement level since the enclaves appear to be the only source for this hybridization and they were already solidified before emplacement of the pluton.

\section{Evolution of the system}

The TMP magmas were generated in an ensialic backarc setting behind the eastward migrating Apenninic front linked to the rollback the Adriatic lithosphere, delamination of the hanging wall plate and consequent mantle uprising (Serri et al. 1993). We propose that mafic magmas produced by decompression melting of hot, uprising mantle probably ponded against the base of the Tuscan crust, or intruded it, with concurrent rapid elevation of the existing isotherms (Fig. 12). A tectonic environment with hot asthenosphere approaching a fertile crust, coupled with ongoing extension in a back-arc setting, is ideal for generating high melt fractions by dehydration melting if muscovite or biotite or hornblende are present in the source (Thompson 1999). This scenario requires that the source rock not equilibrate isotopically (Davies and Tommasini 2000), a likely condition if melting was rapid as is visualized. An initial melt produced by muscovite dehydration melting at approximately $25 \mathrm{~km}$ would have a lower temperature, a lower ${ }^{87} \mathrm{Sr} /{ }^{86} \mathrm{Sr}$ ratio, and probably a higher $\mathrm{SiO}_{2}$ content than subsequent melts resulting from biotite dehydration melting (Patiño 
Douce 1999). This proposed sequence is reminiscent of the preceding phases of magmatism on Elba, the first phase of which formed the Capo Bianco and Portoferraio laccoliths at $8 \mathrm{Ma}$. In that case, a small amount of muscovite dehydration melt was produced initially with lower ${ }^{87} \mathrm{Sr} /{ }^{86} \mathrm{Sr}$ ratios than the much larger volume of biotite dehydration melt that followed (Dini et al. 2002). These melts, however, were extracted sequentially to form discrete intrusions. The second phase produced the San Martino laccolith at 7.4 Ma, consisting of hybridized magma much like that of the Monte Capanne pluton.

Mafic magma entering the crust in large volumes, while serving as a heat source to initiate crustal melting, must immediately start crystallizing as it equilibrates with the colder crust that dominates it volumetrically. Rapid fractionation of this mafic magma may provide additional heat to its surroundings as a cooler, less dense and more siliceous product forms. After sufficient fractionation, this product rises into the softened melt zone, perhaps with rapid transfer of volatiles between the two magmas. Numerous studies have discussed the common occurrence of megacryst-bearing, mafic microgranular enclaves in megacrystic granitoids (Didier and Barbarin 1991 and references therein). This frequent correlation of hybridization and K-feldspar megacryst formation, when seen in view of the Elba magmas with ${ }^{87} \mathrm{Sr} /{ }^{86} \mathrm{Sr}$ ratios dropping during megacryst growth, may suggest that interaction of these magmas contributed in some way to formation of the megacrysts. At this stage, extraction of magma from the melt zone, with entrained enclaves of intermediate composition, would create a dynamic environment, particularly if extraction was rapid as has been postulated for intrusions of similar size with feeder dykes of critical width (Petford et al. 1993). A feeder dyke currently $20 \mathrm{~m}$ wide occurs at the emplacement level of the Monte Capanne pluton having fed the San Martino laccolith whose volume was approximately $20 \mathrm{~km}^{3}$ (Rocchi et al. 2002), indicating that this tectonic setting allowed dyke development with critical widths.

Mixing and mingling during transport would cause the ${ }^{87} \mathrm{Sr} /{ }^{86} \mathrm{Sr}$ ratio in the felsic melt to drop as it was hybridized by interacting with enclave materials having lower ${ }^{87} \mathrm{Sr} /{ }^{86} \mathrm{Sr}$ ratios (Dini et al. 2002; Poli et al. 2002), thus affecting the Kfeldspar megacryst rims and the matrix phases (Fig. 9b). At the same time, accessory minerals that formed in magmas of more extreme composition would suffer disequilibrium when transferred between these interacting magmas. Crystal transfer and other hybridization mechanisms probably reached a maximum during transport as both magma types evolved until the enclaves were eventually digested or solidified.

The final influence generating variations within the pluton was the sequence of emplacement that produced the distribution of the facies. Given that their distinctions most notably involve variations in abundances of K-feldspar megacrysts and enclaves, these differences probably developed prior to reaching the emplacement level. The patchy distribution of the Sant'Andrea facies, dominantly around the margin of the pluton but also in the interior, suggests that it arrived first and was then disturbed by arrival of the San Piero facies. This sequence is not only in keeping with the physical distribution where the facies are generally separated by the intermediate San Francesco facies, but it also fits the model of progressive hybridization during transport whereby the first magma to arrive would be least hybridized. Once emplaced, final crystallization of matrix phases would simply solidify the system, preparing the way for emplacement of late fractionation products and the Orano dyke swarm.

\section{CONCLUSIONS}

Although it is intuitively obvious that complex volcanic eruptive sequences did not develop their complexity at their emplacement level (the surface), such conclusions are not always clear for complex plutons. In the case of the Monte Capanne pluton and its related rocks, we find that K-feldspar megacrysts and their inclusions may reveal the earliest crustal melting history, whereas mafic microgranular enclaves can bear witness to the early fractionation and mixing of mantlederived products with magmas from the crust. Textural and chemical study of all the products, along with disequilibrium reaction textures of early accessory phases, contribute to the conclusion that the Monte Capanne system started evolving from the moment the source rock yielded melt, and that nearly all the observed variations developed at depth, prior to final emplacement.

\section{ACKNOWLEDGEMENTS}

We wish to thank Robert Wiebe who, during his GSA Field Forum, inspired us to look down (even though he was trying to get us to look up for links with volcanic activity). We also wish to thank Martin Feely and an unnamed reviewer for their constructive comments and suggestions. This work was carried out with the financial support of MIUR and CNR grants, and with funding from Norwich University.

\section{REFERENCES}

Boccaletti, M., \& Papini, P. 1989. Richerche meso e microstrutturali sui corpi ignei Neogenici della Toscana. 2: L'intrusione del M. Capanne (isola d'Elba). Bollettino della Società Geologica Italiana, 108, pp. 699-710.

Bouillin, J.-P., Bouchez, J.-L., Lespinasse, P. \& Pecher, A. 1993. Granite emplacement in an extensional setting: an AMS study of the magmatic structures of Monte Capanne (Elba Island, Italy). Earth and Planetary Science Letters, 118, pp. 263-279.

Brunet, C., Monié, P., Jolivet, L., \& CAdet, J.P. 2000. Migration of compression and extension in the Tyrrhenian Sea, insights from ${ }^{40} \mathrm{Ar} /{ }^{39} \mathrm{Ar}$ ages on micas along a transect from Corsica to Tuscany. Tectonophysics, 321, pp. 127-155.

Bussy, F. 1990. Pétrogenèse des enclaves microgrenues associées aux granitoïds calco-alcalins: exemple des massifs 
varisque du Mont-Blanc (Alpes occidentales) et miocène du Monte Capanne (Ile d'Elbe, Italie). Mémoires de Géologie, pp. 309.

Bussy, F. 1991. Enclaves of the Late Miocene Monte Capanne granite, Elba Island, Italy. In Enclaves and Granite Petrology. Edited by J. Didier, and B. Barbarin. Elsevier, pp. 167-178.

Cuney, M., \& Friedrich, M. 1987. Physicochemical and crystal-chemical controls on accessory mineral paragenesis in granitoids: implications for uranium metallogenesis. Bulletin de Mineralogie, 110, pp. 235-247.

DANiEl, J.-M., \& Jolivet, L. 1995. Detachment faults and pluton emplacement: Elba Island (Tyrrhenian Sea). Bulletin de la Société Géologique de France, 166, pp. 341-354.

Davies, G.R., \& Tommasini, S. 2000. Isotopic disequilibrium during rapid crustal anatexis: implications for petrogenetic studies of magmatic processes. Chemical Geology, 162, pp. 169-191.

Deino, A., Keller, J.V.A., Minelli, G., \& Pialli, G. 1992. Datazioni ${ }^{39} \mathrm{Ar} /{ }^{40} \mathrm{Ar}$ del metamorfismo dell'Unità di Ortano-Rio Marina (Isola d'Elba): risultati preliminari. Studi Geologici Camerti, Volume Speciale 1992/2, CROP 1-1A, pp. 187-192.

DiDIER, J., \& BARBARIN, B. 1991. Enclaves and Granite Petrology. Developments in Petrology, 13, Elsevier, 625 p.

DinI, A. 1997. Le rocce porfiriche dell'isola d'Elba: geologia, geocronologia e geochimica: Unpublished $\mathrm{PhD}$ thesis, University of Pisa, $217 \mathrm{p}$.

Dini, A., Innocenti, F., Rocchi, S., Tonarini, S., \& WesterMAN, D.S. 2002. The magmatic evolution of the late Miocene laccolith-pluton-dyke granitic complex of Elba Island, Italy. Geological Magazine, 139, pp. 257-279.

Dini, A., Rocchi, S., \& Westerman, D. S. 2004. Reaction microtextures of REE-Y-Th-U accessory minerals in Mount Capanne pluton (Elba Island Italy): a possible indicator of hybridization processes. Lithos, [in press.]

Harris, N., Vance, D., \& Ayres, M. 2000. From sediment to granite: timescales of anatexis in the upper crust. Chemical Geology, 162, pp. 155-167.

HupPERT, H.E., \& SPARKs, R.S.J. 1988. The generation of granitic magmas by intrusion of basalt into continental crust. Journal of Petrology, 29, pp. 599-624.

Innocenti, F., Serri, G., Ferrara, G., Manetti, P., \& TonARINI, S. 1992. Genesis and classification of the rocks of the Tuscan Magmatic Province: thirty years after Marinelli's model. Acta Vulcanologica, 2, pp. 247-265.

InNocenti, F., Westerman, D.S., Rocchi, S., \& Tonarini, S. 1997. The Montecristo monzogranite (Northern Tyrrhenian Sea, Italy): a collisional pluton in an extensional setting. Geological Journal, 32, pp. 131-151.

Jolivet, L., Daniel, J. M., Truffert, C., \& Goffé, B. 1994. Exhumation of deep crustal metamorphic rocks and crustal extension in arc and back-arc regions. Lithos, 33, pp. 3-30.

Juteau, M., Michard, A., Zimmermann, J.-L., \& Albarede, F. 1984. Isotopic heterogeneities in the granitic intrusion of
Monte Capanne (Elba Island, Italy) and dating concepts. Journal of Petrology, 25, pp. 532-545.

Keller, J.V.A., \& Pialli, G. 1990. Tectonics of the island of Elba: a reappraisal. Bollettino della Società Geologica Italiana, 109, pp. 413-425.

KNESEL, K.M., \& DAvidson, J.P. 2002. Insights into collisional magmatism from isotopic fingerprints of melting reactions. Science, 296, pp. 2206-2208.

Le Bas, M.J., Le Maitre, R.W., Streckeisen, A., \& ZanetTIN, B. 1986. A chemical classification of volcanic rocks based on the total alkali - silica diagram. Journal of Petrology, 27, pp. 745-750.

Malinverno, A., \& Ryan, W.B.F. 1986. Extension in the Tyrrhenian Sea and shortening in the Apennines as result of arc migration driven by sinking of the lithosphere. Tectonics, 5 , pp. 227-245.

MARINELLI, G. 1955. Le rocce porfiriche dell'Isola d'Elba. Atti della Società Toscana di Scienze Naturale (Serie A), LXII, pp. 269-418.

MARINELli, G. 1959. Le intrusioni terziare dell'isola d'Elba. Atti della Società Toscana di Scienze Naturale (Serie A), LXVI, pp. 50-253.

Middlemost, E.A.K. 1994. Naming materials in the magma/igneous rock system. Earth-Science Reviews, 37, pp. 215-224.

Nicolich, R. 2001. Deep seismic transects. In Anatomy of an Orogen: the Apennines and Adjacent Mediterranean Basins. Edited by G.B Vai, and I.P. Martini. Kluwer Academic Publishers, pp. 47-52.

Patiño Douce, A.E. 1999. What do experiments tell us about relative contributions of crust and mantle to the origin of granitic magmas? In Understanding granites: Integrating new and classical techniques. Edited by A. Castro, C. Fernández, and J.-L. Vigneresse. Geological Society Special Publication 168, pp. 55-75.

Pertusati, P., Raggi, G., Ricci, C., Duranti, S., \& PalmERI, R. 1993. Evoluzione post-collisionale dell'Elba centroorientale. Memorie della Società Geologica Italiana, 49, pp. 297-312.

Petford, N., Kerr, R.C., \& Lister, J.R. 1993. Dike transport of granitoid magmas. Geology, 21, pp. 845-848.

Petford, N., Cruden, A.R., McCaffrey, K.J.W., \& VigNERESSE, J.-L. 2000. Granite magma formation, transport and emplacement in the Earth's crust. Nature, 408, pp. 669-673.

PolI, G. 1992. Geochemistry of Tuscan Archipelago granitoids, central Italy: the role of hybridization processes in their genesis. Journal of Geology, 100, pp. 41-56.

Poli, G., \& Tommasini, S. 1991. Model for the origin and significance of microgranular enclaves in calc-alkaline granitoids. Journal of Petrology, 32, pp. 657-666.

Poli, G., Manetti, P., \& Tommasini, S. 1989. A petrological review on Miocene-Pliocene intrusive rocks from southern Tuscany and Tyrrhenian Sea (Italy). Periodico di Mineralogia, 58, pp. 109-126. 
Poli, G., Peccerillo, A., \& Donati, C. 2002. Genesis of Miocene-Quaternary acid rocks from the Tuscan Magmatic Province: some implications for structure of the Apennine lithosphere. Bollettino della Società Geologica Italiana, Volume Speciale N. 1, pp. 129-139.

Rapp, R.P., \& Watson, E.B. 1986. Monazite solubility and dissolution kinetics: implications for the thorium and light rare earth chemistry of felsic magmas. Contributions to Mineralogy and Petrology, 94, pp. 304-316.

Rocchi, S., Westerman, D.S., Dini, A., Innocenti, F., \& TonarinI, S. 2002. Two-stage growth of laccoliths at Elba Island (Italy). Geology, 30, pp. 983-986.

Serri, G., Innocenti, F., \& Manetti, P. 1993. Geochemical and petrological evidence of the subduction of delaminated Adriatic continental lithosphere in the genesis of the Neogene-Quaternary magmatism of central Italy. Tectonophysics, 223, pp. 117-147.

Thompson, A.B. 1999. Some time-space relationships for crustal melting and granitic intrusion at various depths. In Understanding granites: Integrating new and classical techniques. Edited by A. Castro, C. Fernández, and J.L. Vigneresse. Geological Society Special Publication 168, pp. 7-25.

TREVISAN, L. 1950. L'Elba orientale e la sua tettonica di scivolamento per gravità. Memoria della Istituto di Geologia Università di Padova, 16, pp. 1-30.
VERNON, R.H. 1986. K-Feldspar megacrysts in granites - Phenocrysts, not porphyroblasts. Earth Science Reviews, 23, pp. 1-63.

Vernon, R.H., \& Paterson, S.R. 2002. Igneous origin of K-feldspar megacrysts in deformed granite of the Papoose Flat pluton, California, USA. Electronic Geosciences, 7, pp. 31-39.

Vom Rath, G. 1870. Die Insel Elba. Zeitschrift der Deutschen Geologischen Gesellschaft, XXII, pp. 591-732.

Waight, T.E., MaAs, R., \& Nicholls, I.A. 2000. Fingerprinting feldspar phenocrysts using crystal isotopic composition stratigraphy: implications for crystal transfer and magma mingling in S-type granites. Contributions to Mineralogy and Petrology, 139, pp. 227-239.

Westerman, D.S., Innocenti, F., Tonarini, S., \& FerRARA, G. 1993. The Pliocene intrusions of the island of Giglio. Memorie della Società Geologica Italiana, 49, pp. 345-363.

Westerman, D.S., Dini, A., Innocenti, F., \& Rocchi, S. 2004. Rise and fall of a nested Christmas-tree laccolith complex, Elba Island, Italy. In Physical geology of highlevel magmatic systems. Edited by N. Petford and C. Breitkreutz. Geological Society, London. Special Publication 234, pp. 195-213.

Wolf, M.B., London, D. 1995. Incongruent dissolution of REE- and Sr-rich apatite in peraluminous granitic liquids: Differential apatite, monazite, and xenotime solubilities during anatexis. American Mineralogist, 80, pp. 765-775.

Editorial responsibility: David Gibson 